\title{
Rapid sperm acrosome reaction in the absence of acrosomal CD46 expression in promiscuous field mice (Apodemus)
}

\author{
Peter M Johnson, Leanne E Clift, Petra Andrlikova', Michaela Jursova², Brian F Flanagan, \\ Joanne A Cummerson, Pavel Stopka ${ }^{1}$ and Katerina Dvorakova-Hortova ${ }^{2}$ \\ Division of Immunology, School of Infection and Host Defence, University of Liverpool, Duncan Building, Daulby \\ Street, Liverpool L69 3GA, UK, Departments of ${ }^{1}$ Zoology and ${ }^{2}$ Developmental Biology, Faculty of Science, Charles \\ University, Vinicna 7, Prague, Czech Republic
}

Correspondence should be addressed to P M Johnson; Email: mq22@liv.ac.uk

\begin{abstract}
There is pronounced promiscuity and sperm competition in long-tailed field mice (Apodemus sylvaticus). These mice have evolved unusual sperm behaviour favouring rapid fertilisation, including dynamic formation of sperm trains and their subsequent dissociation. The cell surface complement regulatory (CReg) protein CD46 is broadly expressed in eutherian mammals other than rodents, in which it is expressed solely on the spermatozoal acrosomal membrane. Ablation of the CD46 gene has been associated with a faster acrosome reaction (AR) rate in inbred laboratory mice. Here, we demonstrate that wild-caught field mice of three species, A. sylvaticus, A. flavicollis and A. microps, exhibit a more rapid AR than wild-caught house mice Mus musculus or inbred laboratory BALB/c mice. We also demonstrate that wild-caught field mice of these three species, unlike house mice, produce alternatively spliced transcripts of testicular CD46 mRNA lacking exons 5-7 or 6-7, together with an extended $3^{\prime}$ - and often truncated $5^{\prime}$-utr, leading to failure to express any sperm CD46 protein in both the testis and epididymis. Male field mice may therefore have traded expression of this CReg protein for acrosomal instability, providing a novel genus-specific strategy to favour rapid fertilisation and competitive advantage in the promiscuous reproductive behaviour of wild field mice.

Reproduction (2007) 134 739-747
\end{abstract}

\section{Introduction}

Field mice are highly territorial and there is a pronounced sperm competition for individual mating success in their natural environment, reflected in males by their disproportionately large testicles (Breed \& Taylor 2000, Bryja \& Stopka 2005). In Apodemus sylvaticus (A. sylvaticus, long-tailed field mouse; wood mouse), mechanisms have evolved to facilitate rapid fertilisation, such as dynamic formation of sperm 'trains' with significantly increased progressive motility (Moore et al. 2002). Up to $50 \%$ of these spermatozoa may undergo a spontaneous acrosome reaction (AR) within an hour, which is also believed to be associated with the essential dissociation of sperm trains (Moore et al. 2002). Rapid fertilisation would temporally assist individual males within this highly promiscuous species and represent a mechanism selected by $A$. sylvaticus males to compete between each other at the cellular level.

CD46 (membrane cofactor protein) is a widely expressed cell surface protein in humans and most other mammals and is a key complement regulatory (CReg) protein protecting host cells from complement-mediated damage. Human CD46 is a type I transmembrane glycoprotein composed primarily of four extracellular domains, termed short consensus repeats (SCRs), and occurs in many isoforms generated by alternative splicing of three short exons encoding serine/threonine/proline (STP)-rich regions and two exons encoding different cytoplasmic tail (CYT) regions (Liszewski \& Atkinson 1992). CD46 cross-linking initiates intracellular signalling events in various cell types, including T lymphocytes (Wong et al. 1997, Wang et al. 2000, Marie et al. 2002, Kemper et al. 2003, Liszewski etal. 2005). Furthermore, CD46 functions as a cell surface receptor for a diverse range of microbial pathogens (Cattaneo 2004, Liszewski et al. 2005).

However, in sperm, CD46 is expressed solely as an unusual lower molecular weight hypoglycosylated isoform localised to the acrosomal membrane and becomes surface exposed only after sperm have acrosome reacted (Anderson et al. 1989, Cervoni et al. 1992, Riley et al. 2002a). The AR is a critical $\mathrm{Ca}^{2+}$-dependent event that follows capacitation, enabling sperm to be fusion competent after exocytosis of the single giant enzymerich secretory vesicle, the acrosome. This results in morphological change and remodelling of the anterior sperm head. Monoclonal antibodies to the first SCR (SCR1) ectodomain of CD46 block the complementindependent interaction of human sperm with zona-free oocytes in vitro (Anderson et al. 1989, 1993, Okabe et al. 
1990, Taylor et al. 1994, D'Cruz et al. 1997). New World monkeys selectively express an alternatively spliced CD46 isoform lacking SCR1 on all cells except sperm (Riley et al. 2002b), further supporting a key role for the SCR1 ectodomain of CD46 in fertilisation.

In line with this concept, but in contrast to other eutherian mammals, there has been loss of systemic expression of CD46 in rodents and its CReg role has instead been subsumed by Crry, a rodent-specific membrane CReg protein (Hosokawa et al. 1996, Miwa etal. 1998, Tsujimura et al. 1998, Mead etal. 1999). Thus, CD46 protein is expressed in rodents only by mature sperm and spermatozoal precursors in testes with active spermatogenesis (Mizuno et al. 2004). Additionally, anti-CD46 antibody may not block in vivo fertilisation in the rat (Mizuno et al. 2007). The CD46 gene in rodents contains 11 functional exons, in comparison with 14 in humans, and includes a single STP and a single CYT exon; alternative splicing of rodent membrane-bound CD46 has rarely been described.

Since disruption of the CD46 gene in inbred laboratory mice may cause an accelerated AR compared with wild-type mice (Inoue et al. 2003), we hypothesised that there could also be differences in CD46 gene expression in sperm of wild field mice. Here, we have demonstrated that wild-caught $A$. sylvaticus exhibit a more rapid AR than house mice Mus musculus. Furthermore, we show that $A$. sylvaticus fail to express any CD46 protein in both the testis and the epididymis. We extend these observations also to show that two further species within the Apodemus genus (A. flavicollis and $A$. microps) behave similarly to A. sylvaticus.

\section{Results}

\section{Accelerated $A R$ in sperm of wild field mice}

In order to assess the rate of AR under in vitro fertilising conditions for sperm of wild-caught field mice
(Apodemus), and to compare with that for wild-caught house mice (M. musculus), we used Alexa peanut agglutinin (PNA) lectin selective for an intact acrosome. The AR rate for spermatozoa collected from the very distal region of the cauda epididymis was measured at selected times during sperm incubation in M2 fertilising medium. Two subspecies of house mice (M. musculus musculus and M. musculus domesticus), as well as BALB/c mice, were used as reference controls for three field mouse species (A. sylvaticus, A. microps (pygmy field mouse) and A. flavicollis (yellow-necked field mouse)). There was a significantly faster mean rate of AR by sperm of all three species of wild-caught field mice compared with the two subspecies of wild-caught house mice and also BALB/C mice (Fig. 1). There was no obvious difference in viability or motility of sperm between field and house mice in these experiments. The increased rate of $A R$ in field mice is genus specific (ANOVA, $F=30.1$, d.f. $=5$, $P<0.0000001)$. Post hoc Tukey test revealed that wild house mice had significantly lower rates of AR compared with any of the three species within the field mouse genus (A. microps $P<0.01 ; A$. flavicollis $P<0.0003$; $A$. sylvaticus $P<0.0001)$. Furthermore, there was no difference in the rate of AR between $M$. m. musculus, M. $m$. domesticus and inbred BALB/C $(P>0.6)$. There was also no difference between $A$. microps and $A$. flavicollis $(P=0.68)$.

\section{Alternatively spliced A. sylvaticus testicular CD46 mRNA}

Since wild field mice are comparable with inbred $C D 46^{-1-}$ gene knockout mice regarding a more rapid AR rate (Inoue et al. 2003), we investigated whether they were also phenotypically homologous with respect to expression of mature CD46 protein. Conserved primer pairs were designed using published mouse (M. musculus) and rat (Rattus norvegicus) CD46 consensus gene sequences from within exons, flanking individual exons or spanning

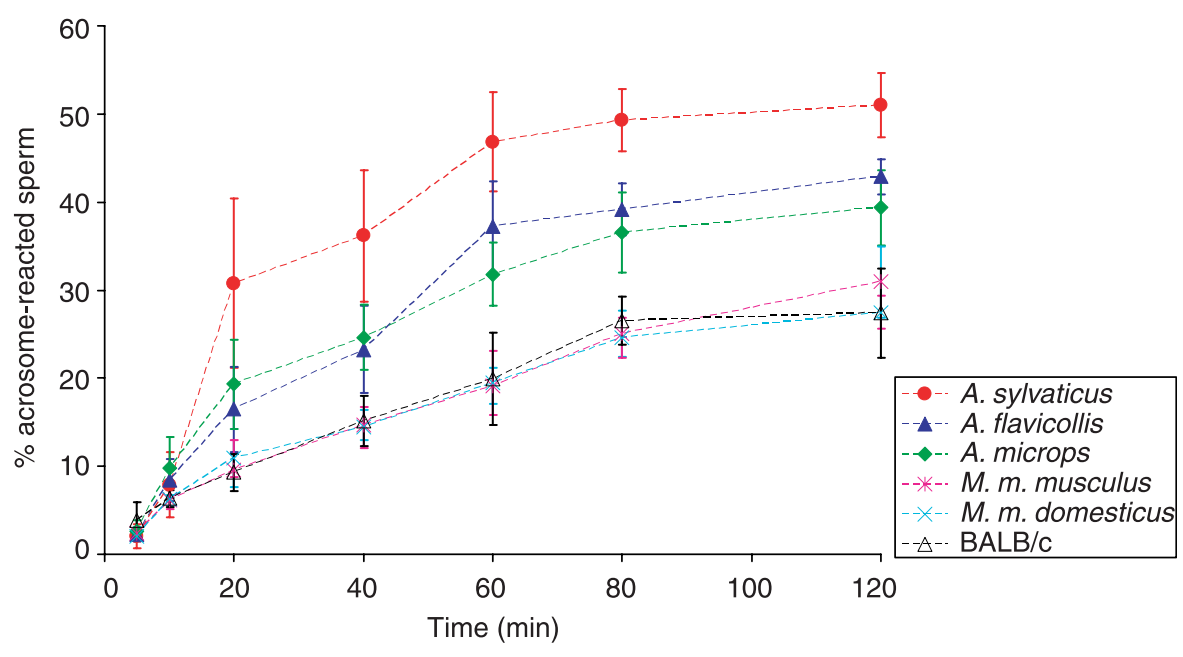

Figure 1 The acrosome reaction is significantly faster in three different species of wild-caught field mice (Apodemus) compared with house mice (Mus musculus). Each datum point represents eight separate experimental observations. 
individual intron/exon divides. These primers were used in PCR on genomic DNA from wild-caught A. sylvaticus, followed by sequencing of amplicons, to derive full or partial sequences of $A$. sylvaticus CD46 exons 1, 2, 3, 5 and 11. Further sets of exon-specific primers were then designed to span separate exonic sequences and used in RT-PCR to interrogate testicular mRNA from A. sylvaticus compared with BALB/c mice. It became clear that there is a significant sequence deletion of 432 nucleotides in $A$. sy/vaticus compared with BALB/c testicular CD46 cDNA (Fig. 2; lanes 2 and 3). Sequencing demonstrated that exons 5-7 were absent. Further PCR analysis using a primer for exon 5 revealed that some transcripts instead lacked only exons 6-7 (Fig. 2; lanes 4 and 5). After obtaining partial A. sylvaticus mRNA sequence information, this approach was repeated with additional sets of primers, supplemented by both $5^{\prime}$ - and $3^{\prime}-\mathrm{RACE}$, in order to derive the full-length A. sylvaticus CD46 testicular cDNA sequence. This complete sequence, lacking exons 6 and 7 , is shown in Fig. 3, together with the predicted A. sylvaticus amino acid sequence. Compared with published sequences (Miwa et al. 1998, Tsujimura et al. 1998, Mead et al. 1999), A. sylvaticus CD46 shows $91.2 \%$ nucleotide homology with Mus, and $86.2 \%$ with Rattus; $4.0 \%$ of nucleotides were specific for $A$. sylvaticus. This sequence is compatible with the phylogenetic position of Apodemus between the Rattus and Mus genera (Michaux et al. 2002). The A. sylvaticus CD46 testicular cDNA sequence is in-frame, has no premature stop codon and retains characteristic conserved sequences for CD46. Primers used for PCR, RT-PCR and RACE are listed in Table 1.

Thus, two separate mRNA transcripts have been identified for $A$. sylvaticus testicular CD46, one lacking exons 5-7 and the other lacking exons 6 and 7. These would be predicted to encode CD46 proteins that exclude the SCR3 (exon 5), SCR4 (exon 6) and STP (exon 7) regions. Although alternative splicing of CD46 is common in primates, it has not been described for transmembrane CD46 in rodents other than some guinea pig CD46 cDNA

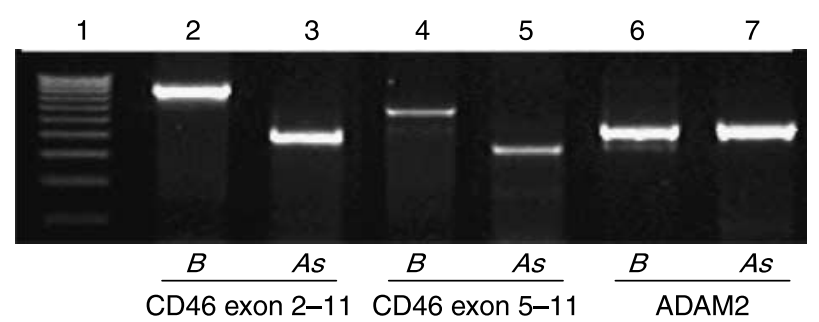

Figure 2 CD46 transcripts are shorter in A. sylvaticus than in BALB/C mice. PCR of CDNA prepared from testicular extracts. 1, Ladder. 2 and 3, CD46 exon 2-11 primer set giving products of $822 \mathrm{nt}$ (BALB/c) and 390nt (A. sylvaticus) respectively. 4 and 5, CD46 exon 5-11 primer set giving products of $585 \mathrm{nt}(\mathrm{BALB} / \mathrm{c})$ and $326 \mathrm{nt}$ ( $A$. sylvaticus) respectively. 6 and 7, primer set corresponding to nt 972-1412 of M. $m$. musculus ADAM2 (A disintegrin and metalloprotease 2) CDNA, used as a positive control for testicular cDNA, giving a 440nt product for both BALB/C and A. sylvaticus. B, BALB/C; As, A. sylvaticus. clones that lacked the exon encoding either the SCR4 or the STP domain, which were identified in addition to fulllength cDNA clones (Hosokawa et al. 1996).

In A. sylvaticus CD46 mRNA, there is a 54 nt sequence extension to the $3^{\prime}$-utr that is AU-rich (74.1\%; Fig. 3). AU-rich elements in the $3^{\prime}$-utr are associated with destabilisation of RNA and can provide mechanisms for suppressing gene expression initiated by deadenylation and subsequent degradation through exonuclease complexes. There has been recent recognition of the relative importance of the $5^{\prime}-3^{\prime}$ decay pathway (Stoecklin et al. 2006). In line with this concept, although RT-PCR using a $5^{\prime}$-terminal exon 1 primer amplified $A$. sylvaticus testicular CD46 cDNA, use of 5'-RACE often identified amplicons lacking between 165 and 199nt from exon 1 and the $5^{\prime}$-terminal sequence of exon 2 , and hence without the ribosomal binding site and translation start codon. In contrast, amplicons produced by $5^{\prime}$-RACE reactions in Mus consistently included the complete exon 1 and 2 sequences. This raised the possibility that CD46 is not translated in the A. sylvaticus testis.

\section{CD46 protein is not expressed in A. sylvaticus testis or sperm}

Accordingly, we raised a rabbit antiserum against a 14-mer peptide (PFEAMELKGTPKLY) that was homologous with amino acids $50-63$ of the predicted $A$. sylvaticus CD46 SCR1 amino acid sequence, but with a single amino acid difference from the published $M$. musculus sequence (PFEAMELKGTPKLF; Miwa et al. 1998, Tsujimura et al. 1998). The peptide was conjugated to keyhole limpet haemocyanin $(\mathrm{KLH})$ for immunisation and antiserum bleeds screened by ELISA against peptide conjugated to BSA. High-titre antibody was affinity purified using non-conjugated peptide immobilised to an agarose gel support. The immune antiserum gave an $\mathrm{OD}_{405} \mathrm{~nm}$ $1.40 \pm 0.01$ at $1: 3200$ dilution in ELISA against BSApeptide, whereas it was $0.11 \pm 0.01$ at the same dilution against BSA alone; pre-immune serum gave $\mathrm{OD}_{405 \mathrm{~nm}}$ values of $0.13 \pm 0.01$ and $0.12 \pm 0.01$ at $1: 3200$ dilution against BSA-peptide and BSA alone respectively. We also included a polyclonal rat anti-rat CD46 antiserum (Mizuno et al. 2007).

In immunocytochemistry on permeabilised epididymal sperm from wild-caught $M$. musculus as well as inbred $\mathrm{BALB} / \mathrm{C}$ mice, the rabbit anti-CD46 peptide antibody clearly stained only the acrosomal region, whereas there was no corresponding staining of wild-caught $A$. sylvaticus sperm (Figs 4A and 5). This acrosomal staining of M. musculus sperm was completely inhibited by preincubation of the rabbit anti-CD46 peptide antibody with a 50 molar excess of either the free peptide or the BSA-peptide conjugate. Similarly, the rat anti-rat CD46 antiserum stained the acrosomal region of epididymal sperm from wild-caught $M$. musculus, inbred BALB/c mice and Wistar rats but gave no corresponding staining of 


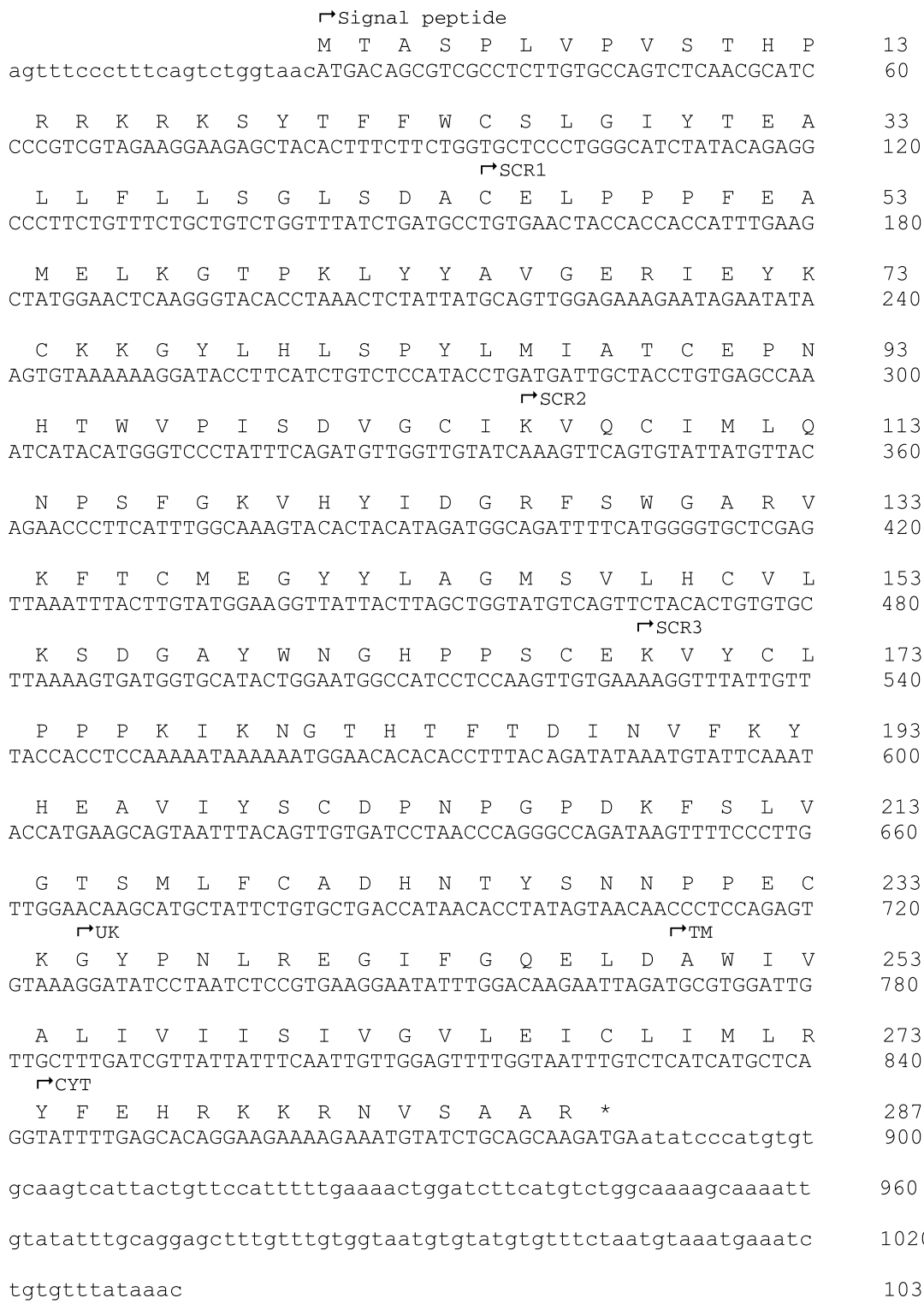

A. sylvaticus sperm (Fig. 4B). In addition, both the rabbit anti-CD46 peptide antibody and the rat anti-rat CD46 antiserum gave clear immunohistochemical staining of spermatids and spermatozoa in M. musculus and BALB/C mouse testis but no staining in A. sylvaticus testis (Fig. 4C). Furthermore, seven separate mouse monoclonal antibodies (MM1, 2, 3, 4, 5, 8 and 9) against rat CD46 (Mizuno et al. 2004, 2005, Mizuno et al. unpublished observations) clearly stained Wistar rat but not $A$. sy/vaticus epididymal sperm (data not shown).

\section{CD46 protein is not expressed in other Apodemus testis or sperm}

We then investigated spermatozoal and testicular expression of CD46 protein, as well as CD46 transcripts, in a variety of other wild-caught Apodemus and Mus taxa within the muroid clade. As with A. sylvaticus, expression of CD46 protein could not be detected immunocytochemically in either testicular or epididymal sperm of the other field mice, A. flavicollis and A. microps, using both the rabbit anti-CD46 peptide antibody and rat anti-rat CD46 polyclonal antiserum, whereas M. m. musculus and M. m. domesticus house mice clearly expressed this protein - i.e. the same immunostaining patterns as depicted in Figs 4 and 5 (data not shown). Similarly, both house mice subspecies expressed identical testicular CD46 mRNA transcripts to sequences derived from inbred BALB/C mice (Fig. 6A). In contrast, both $A$. flavicollis and $A$. microps field mice expressed comparable alternatively spliced testicular CD46 mRNA sequences to $A$. sylvaticus in respect of the exon $5-7$ deletion (Fig. $6 \mathrm{~B})$ and the AU-rich $(74.1 \%$ and $75.9 \%$ respectively) $3^{\prime}$-utr sequence extension (Fig. $6 \mathrm{C}$ ). 
Table 1 Primers used for PCR, RT-PCR, 5'-RACE and $3^{\prime}$-RACE reactions where amplicons were subsequently sequenced.

\begin{tabular}{|c|c|}
\hline Primer sequence & Primer description \\
\hline \multicolumn{2}{|l|}{ PCR primer sequences } \\
\hline CCGATTGGCCTAGCTAGC & $\begin{array}{l}\text { CD46 } 5^{\prime} \text {-flanking to } \\
\text { exon } 1 \text {, sense }\end{array}$ \\
\hline СGACACAGССТСТСТССТ & CD46 intron 1 , anti-sense \\
\hline GTCTCTAGATGCCTGTGAAC & CD46 intron 1 -exon 2 , sense \\
\hline GCCСAATTAAACCTGGTCAT & CD46 intron 2, anti-sense \\
\hline TTGATTCAAGTGCAACTGG & CD46 intron 2, sense \\
\hline TATTTAACTCGAGCACC & CD46 exon 3 , anti-sense \\
\hline TGGAACACACACCTTTAC & CD46 exon 5, sense \\
\hline СTTTACACTCCGGAGGGT & CD46 exon 5 anti-sense \\
\hline AAATGTATCTGCAGCAAG & CD46 exon 11 , sense \\
\hline GAAGCTCCTGCAAATAT & CD46 exon 11 , anti-sense \\
\hline \multicolumn{2}{|l|}{$R T-P C R$ primer sequences } \\
\hline CCTTCTGTTTCTGCTGTCT & CD46 exon 1 , sense \\
\hline AATCATACATGGGTCССТА & CD46 exon 2 , sense \\
\hline TAGGGACCCATGTATGATT & CD46 exon 2, anti-sense \\
\hline ACTACATAGATGGCAG & CD46 exon 3 , sense \\
\hline CTGCCATCTATGTAGT & CD46 exon 3 , anti-sense \\
\hline ATTGTTTACCACCTCCA & CD46 exon 5 , sense \\
\hline TGGAACACACACCTTTAC & CD46 exon 5 , sense \\
\hline CGATCAAAGCAACAATC & CD46 exon 9 anti-sense \\
\hline TTCATCTTGCTGCAGATAC & CD46 exon 11 , anti-sense \\
\hline AGCTGCTGAGCCTCAGCATG & ADAM2, sense \\
\hline ATGTGCCGTTGCAGTACTCT & ADAM2, anti-sense \\
\hline \multicolumn{2}{|l|}{$3^{\prime}-R A C E$ primer sequences } \\
\hline TGGAACACACACCTTTAC & $\begin{array}{l}\text { Gene-specific primer } \\
\text { (GSP) } 1, \text { CD } 46 \text { exon } 5\end{array}$ \\
\hline AAATGTATCTGCAGCAAG & GSP2, CD46 exon 11 \\
\hline GACTCGAGTCGACATCGA & Adaptor primer (AP) \\
\hline GACTCGAGTCGACATCGA $(\mathrm{T})_{17} \mathrm{G}$ & AP-polyT-G \\
\hline \multicolumn{2}{|l|}{$5^{\prime}-R A C E$ primer sequences } \\
\hline AATTTAGCTCGAGCACC & GSP3, CD46 exon 3 \\
\hline СTGCCATCTATGTAGT & GSP4, CD46 exon 3 \\
\hline TAGGGACCCATGTATGATT & GSP5, CD46 exon 2 \\
\hline GACTCGAGTCGACATCGA & $\mathrm{AP}$ \\
\hline GACTCGAGTCGACATCGA $(G)_{17}$ & AP-polyG \\
\hline
\end{tabular}

Like A. sylvaticus, but unlike both house mice subspecies, 5'-RACE reactions in the two other Apodemus species often terminated prematurely in exon 2.

\section{Polymorphism in Apodemus testicular CD46 mRNA}

There was minor nucleotide sequence polymorphism between the three Apodemus taxa (see Supplementary Figure 1, which can be viewed online at www.reproduction-online.org/supplemental/, for full Apodemus taxa CD46 sequence information compared with M. musculus). In addition, complete sequencing of testicular CD46 mRNA transcripts from five wild-caught $A$. sy/vaticus mice identified further polymorphisms between individuals involving seven nucleotide positions in the coding region and four nucleotide positions in non-coding flanking regions (also see Supplementary Figure 1). Comparable polymorphisms were also noted for $A$. flavicollis and A. microps. This was unexpected for Apodemus since genetic polymorphism has not previously been described for the coding region of rodent CD46. Analysis of the
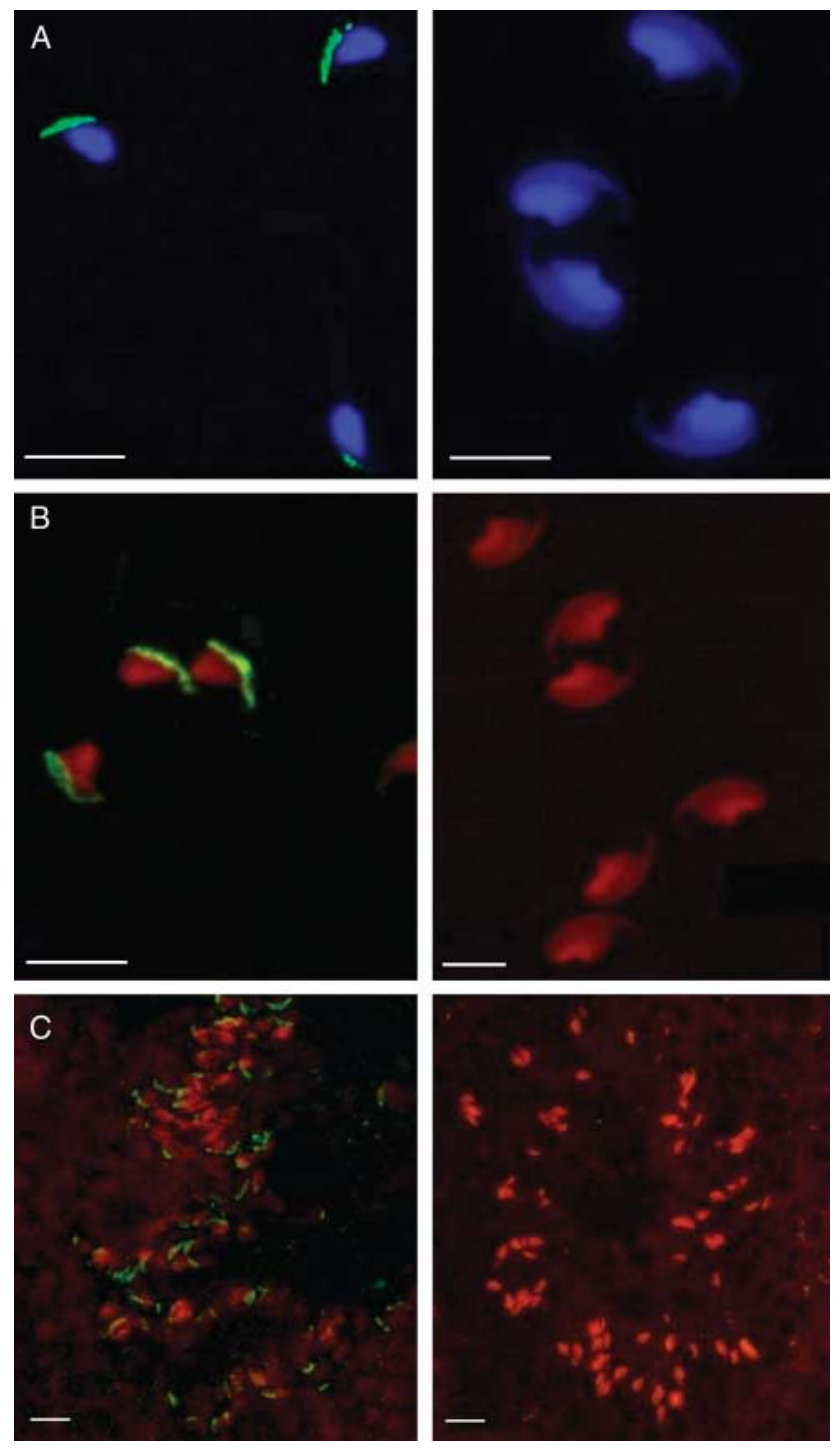

Figure 4 CD46 protein is expressed by M. m. musculus but not A. sylvaticus sperm. Immunostaining for CD46 (green) in the acrosomal region of sperm from M. m. musculus (left panels) and A. sylvaticus (right panels). (A) Affinity-purified rabbit polyclonal antibody against A. sylvaticus CD46 SCR1 peptide on epididymal sperm; (B) rat polyclonal antiserum against rat CD46 on epididymal sperm; (C) rat polyclonal antiserum against rat CD46 on testicular spermatozoa. Nuclei counterstained with DAPI (blue) or propidium iodide (red). $5 \mu \mathrm{m}$ cryosection. Scale bars represent $10 \mu \mathrm{m}$.

origin of individual A. sylvaticus mice revealed a correlation with having been caught in either western (Bohemia) or eastern (Moravia) Czech Republic. Since the majority $(71 \%)$ of the polymorphisms within the coding region would result in an amino acid change in any translated protein (i.e. non-synonymous changes), they may represent positive selection driving evolution of gamete recognition proteins (Levitan \& Ferrell 2006) in competitive breeding within the Apodemus taxa prior to the advent of failure to express CD46 protein, as may also be the case for the unique CD46 splicing. These events 

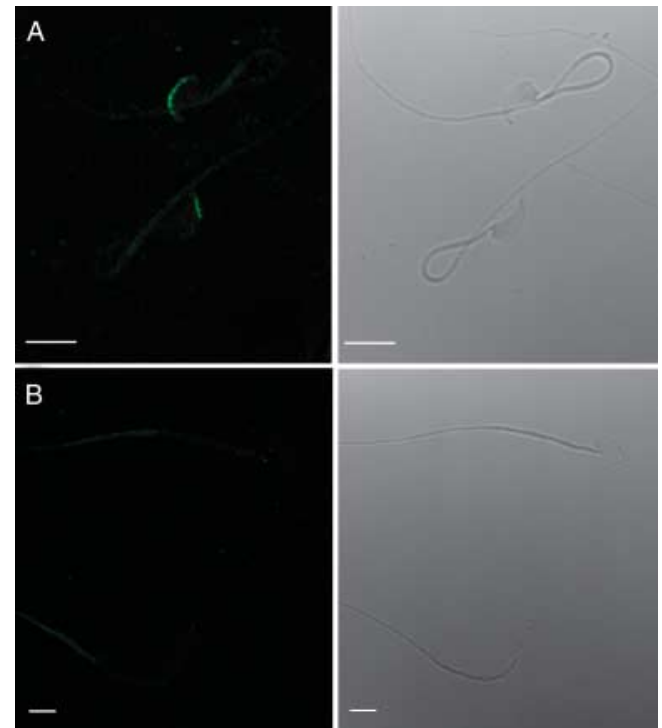

Figure 5 Affinity-purified rabbit polyclonal antibody against $A$. sylvaticus CD46 SCR1 peptide on epididymal sperm (left panels) and corresponding phase-contrast micrographs showing the morphological status of the acrosomal region (right panels); (A) BALB/C sperm; (B) A. sylvaticus sperm. Scale bars represent $8 \mu \mathrm{m}$.

could have occurred independently during the rapid species radiation into ecologically specialised taxa (Serizawa et al. 2000).

\section{Discussion}

In the present study, we have demonstrated a rapid $\mathrm{AR}$ and the absence of spermatozoal CD46 in three species of wild-caught field mice (Apodemus). In contrast, wildcaught house mice (M. musculus) express CD46 and take longer to undergo the $A R$, behaving exactly the same as inbred BALB/c mice. Thus, field mice, in comparison with house mice, are naturally occurring null phenotypic analogues to $\mathrm{CD} 46^{-1-}$ gene knockout mice (Inoue et al. 2003) with respect to a more rapid mean AR rate and higher fertilising ability. Similarly, these field mice do not exhibit any abnormalities in spermatogenesis or fertilisation, further supporting the concept that the primary role of CD46 on acrosome-reacted sperm is not protection from attack by the abundant complement in the oviducts. Instead, spermatozoal CD46 in rodents is more likely associated with acrosomal integrity within the sperm head, and the absence of molecular expression of CD46 protein in field mice may favour rapid fertilisation and individual competitive advantage in their promiscuous reproductive behaviour. The mechanism by which the presence of acrosomal membrane CD46 stabilises this organelle is unknown. This could involve actin reorganisation following protein kinase signalling directly upon CD46 stimulation (Wong et al. 1997, Zaffan et al. 2001) or specific CD46 binding to $\beta 1$-integrins and subsequent indirect associations through the integrin tail anchor
A

CD46 exon 2-11

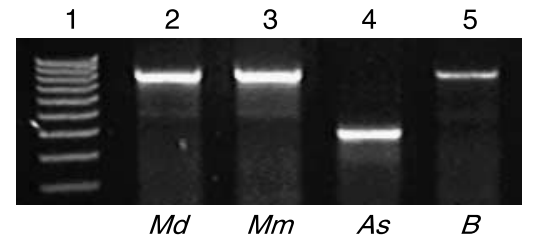

B

CD46 exon 2-11

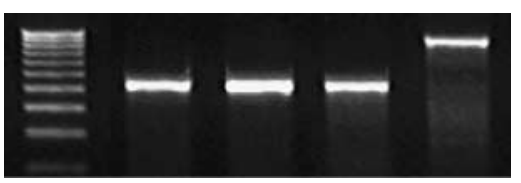

Af

C

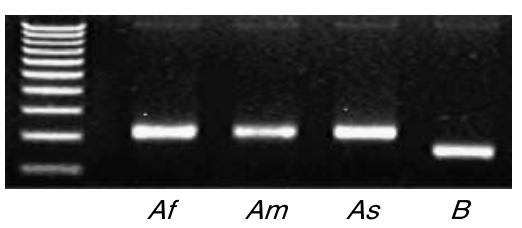

Figure 6 Different species of field mice (Apodemus) all have shorter CD46 transcripts with a 3'-utr extension compared with house mice (M. musculus). PCR of cDNA prepared from testicular extracts. (A) 1, Ladder. 2-5, CD46 exon 2-11 primer set giving a product of 822nt for M.m. domesticus and M. m. musculus, as well as BALB/C mice, compared with a product of 390nt for A. sylvaticus. (B) 1, Ladder. 2-5, CD46 exon 2-11 primer set giving a product of 390nt for A. flavicollis, A. microps and A. sylvaticus, but a product of 822nt for BALB/C mice. (C) 1, Ladder. 2-5, 3'-RACE giving a product of 204nt for A. flavicollis, A. microps and A. sylvaticus, compared with a product of $150 \mathrm{nt}$ for BALB/c mice. Af, A. flavicollis; Am, A. microps; As, A. sylvaticus; $B, \mathrm{BALB} / \mathrm{c}$.

to the surrounding cortical cytoskeleton during its restructuring throughout capacitation (Lozahic et al. 2000, Kurita-Taniguchi et al. 2002, Rezcallah et al. 2005). The induction of a calcium flux on CD46 signalling (Källström et al. 1998) may be particularly relevant to the acrosomal membrane. These issues relating to acrosomal stability could be restricted to the rodent superfamily Muroidea with the apical hook-shaped falciform sperm head morphology that is unique within eutherian mammals.

It appears that the genus Apodemus has developed during phylogeny to exceptionally select two CD46 transcripts with exons 5, 6 and 7 spliced out, a 54nt $3^{\prime}$-utr sequence extension and often a 5 '-terminal sequence deletion, which together prevent functional CD46 protein translation and expression on sperm. An additional non-exclusive hypothesis is that field mouse sperm CD46 might become rapidly ubiquitinated and undergo proteosomal degradation within the acrosome; it has been reported that inhibition of mouse sperm proteosomal activity may block acrosomal exocytosis (Pasten et al. 2005). Nevertheless, the consequence is that expression of CD46 is traded in field mouse sperm cells for an accelerated AR, fast-tracking zona pellucida (ZP) penetration through a high concentration of lytic enzymes at the fertilisation site. This is in line with a concept that males may trade aspects of immune 
competence for competitive sperm advantage in certain species (Simmons \& Roberts 2005). Sperm would still be protected against locally activated complement by expression of other CReg proteins and, indeed, CD46independent deposition of activated $\mathrm{C} 3$ on the acrosomereacted sperm head may be beneficial for fertilisation at least in humans (Riley-Vargas et al. 2005).

CD46 has been utilised as a cell surface receptor by numerous pathogenic viruses and bacteria (Cattaneo 2004, Liszewski et al. 2005), and differential tissue expression of CD46 could be a result of selective pressure from these pathogens. In promiscuous field mouse species, with high exposure to genital pathogens, it may be advantageous not to express certain pathogen receptors such as CD46. Thus, there could be pathogendriven rather than reproduction-driven selective loss of spermatozoal CD46 in field mice. However, the short period of time between surface exposure of spermatozoal CD46 and potential fertilisation would argue against the former mechanism.

As spermatozoa reside in the female reproductive tract, progressively more undergo capacitation followed by the AR, such that over $40 \%$ have acrosome reacted by the time sperm are in the oviducts of inbred mice (Klemm \& Engel 1991). Sperm competition influences sperm function by increasing the proportion that capacitate, selecting for sperm that are more sensitive to signals released by the ovum to undergo the AR at the site of fertilisation (Gomendio et al. 2006). This would be expected to be exaggerated in wild field mice, and the consequence of premature loss of the acrosomal content would be compatible with other reproductive biological traits of Apodemus. There is pronounced sperm competition for individual mating success, reflected by the more promiscuous behaviour and large testicles of field mice as well as sperm morphological adaptations in this species-rich rodent subfamily (Breed \& Taylor 2000, Bryja \& Stopka 2005, Immler et al. 2007). These factors are reflected in mechanisms that have evolved in field mice to facilitate rapid fertilisation, such as dynamic sperm 'trains' and an AR completed within a 60-min period for greater than $50 \%$ of sperm, which may assist both dissociation of these trains (Moore et al. 2002) and bypass the primary binding of acrosome-unreacted sperm to ZP (Myles et al. 1987, Yamagata et al. 2002). The release of acrosomal contents within a short time period can facilitate ZP structural weakening and sperm passage, as well as binding of acrosome-reacted sperm to ZP independently of zona protein 3 (Talbot et al. 2003). It has also been demonstrated that only acrosome-reacted sperm can bind to and penetrate the ZP in the guinea pig (Huang et al. 1981), and that acrosome-reacted mouse sperm can fertilise ZP-free eggs and produce normal offspring (Naito et al. 1992).

In conclusion, we have demonstrated unique transcriptional forms of CD46 in wild field mice, not found in other rodents, resulting in loss of CD46 translation in sperm. This may be associated with acrosomal instability, and indeed we have shown that the AR is completed faster in field mice compared with house mice. This contributes a novel molecular basis underlying a genus-specific strategy for more rapid fertilisation and increased competitive advantage in promiscuous field mice.

\section{Materials and Methods}

\section{Mice}

Male mice were caught from regions of Central Bohemia and South Moravia, Czech Republic (A. sylvaticus, A. flavicollis and A. microps), from around Buskovice, Czech Republic (M. m. musculus) and around Straas, Germany (M. m. domesticus). At the time of experiments, all mice were at reproductive age. These mice were maintained in a pathogen-free facility for wild mice at the Department of Zoology, Charles University, Prague, Czech Republic. Laboratory $\mathrm{BALB} / \mathrm{C}$ mice and Wistar rats were maintained in animal facilities in the Department of Developmental Biology, Charles University, Prague, Czech Republic. All animal procedures were carried out in accordance with the Animal (Scientific Procedure) Regulations and subjected to review by the local ethical committee.

\section{$A R$ rate measurement}

Spermatozoa were recovered from the cauda epididymis by placing its very distal region into PBS for $10 \mathrm{~min}$ at $37^{\circ} \mathrm{C}$ in $5 \%$ $\mathrm{CO}_{2}$ in air. Epididymal sperm were capacitated at a concentration of $5 \times 10^{6}$ in $\mathrm{M} 2$ fertilisation medium (SigmaAldrich) under paraffin oil. At times 5, 10, 20, 40, 60, 80 and $120 \mathrm{~min}$, spermatozoa were collected for evaluation of acrosomal status by staining with $5 \mu \mathrm{M}$ Alexa PNA lectin (Molecular Probes, Prague, Czech Republic) and immediately assessed under the epifluorescent microscope. Sperm motility and viability (Sperm Viability Kit; Molecular Probes) was examined throughout all experiments using an inverted microscope with a stage thermostatically controlled at $37^{\circ} \mathrm{C}$; sperm viability was always $>86 \%$.

\section{Extraction of nucleic acid}

Splenic DNA was extracted using the DNeasy Tissue Kit (Qiagen), and RNA extracted from mouse testes using ice-cold Trizol reagent (Invitrogen).

\section{Reverse transcription}

Testicular RNA was reverse transcribed using the Superscript II reverse transcriptase protocol (Invitrogen).

\section{PCR}

PCRs were conducted according to the $2 \times$ ReddyMix PCR master mix protocol (ABgene, Epsom, UK). A murine ADAM2 (fertilin- $\beta$ ) primer set was used in positive control reactions. 
Using $2 \%$ agarose gel electrophoresis, $10 \mu \mathrm{l}$ CD46 and $2 \mu \mathrm{l}$ ADAM2 PCR products were visualised and purified using the QIAquick PCR purification kit gel extraction protocol (Qiagen). In order to confirm sequence identity, or to define new Apodemus sequences, PCR and RACE amplicons were sequenced by primer extension at Lark Technologies (Takeley, UK) using an ABI PRISM Sequence Detection System.

\section{$3^{\prime}-R A C E$}

First-strand cDNA synthesis and amplification of target cDNA steps were identical to the Invitrogen $3^{\prime}$-RACE kit protocol, except that a different adaptor primer (AP) and AP-polyT-G primer were used (see Table 1). An additional nested PCR step was added in which $0.1 \%$ of the product from amplification of target CDNA was re-amplified using a second gene-specific primer (GSP).

\section{$5^{\prime}-R A C E$}

First-strand cDNA synthesis was conducted according to the Invitrogen $5^{\prime}$-RACE kit protocol, except that cDNA was not RNase treated and was ethanol precipitated. Tailing of cDNA was also conducted following this protocol, except that $16.5 \mu \mathrm{l}$ purified cDNA was used instead of $6.5 \mu \mathrm{l}$ and samples incubated with terminal deoxynucleotide transferase for $30 \mathrm{~min}$ instead of $10 \mathrm{~min}$. PCR of tailed cDNA was also conducted according to the Invitrogen 5'-RACE kit protocol, except that a different AP-polyG primer was employed (see Table 1) and the tailed cDNA was used at a 1:40 dilution. An additional nested PCR step was added in which $0.1 \%$ of the product from amplification of tailed cDNA was re-amplified using a second GSP and AP instead of AP-polyG.

\section{Antibodies}

An antiserum was raised in a New Zealand white rabbit against a 14-mer peptide specific to an A. sylvaticus CD46 SCR1 amino acid sequence (PFEAMELKGTPKLY) predicted from the derived cDNA sequence. This peptide was selected based on the prediction that it would be both antigenic and exposed on the surface of CD46 using the Lasergene analytical package (DNASTAR Inc., Madison, WI, USA). The peptide was synthesised using the $m$-maleimidobenzoyl- $N$-hydroxysuccinimide ester method and conjugated via an additional $\mathrm{N}$-terminal cysteine to KLH by Sigma-Aldrich. Antiserum bleeds were screened by ELISA against peptide conjugated to BSA. High-titre antibody was affinity purified on nonconjugated peptide immobilised to an agarose gel support using a Sulfolink kit (Perbio Science, Cramlington, UK) and eluted with $100 \mathrm{mM}$ glycine buffer ( $\mathrm{pH}$ 2.8).

A polyclonal antiserum raised against a recombinant rat CD46 SCR123 fusion protein by immunisation of female rats was a kind gift of B P Morgan, C L Harris and M Mizuno, Cardiff University School of Medicine (Mizuno et al. 2007). Seven separate mouse monoclonal antibodies (MM1, 2, 3, 4, 5, 8 and 9) raised against the rat CD46 SCR123 fusion protein (Mizuno et al. 2004, 2005, Mizuno et al. unpublished observations) were also a kind gift of B P Morgan, C L Harris and M Mizuno. Secondary antibodies conjugated with Alexa Fluor 488 (Molecular Probes) were used at 1:1000 dilution.

\section{Immunohistochemical analysis}

In parallel with the preparation of epididymal sperm smears, testes were also collected for $5 \mu \mathrm{m}$ cryosections. Samples were permeabilised for $10 \mathrm{~min}$ in acetone pre-cooled at $-20{ }^{\circ} \mathrm{C}$, airdried, blocked for $1 \mathrm{~h}$ with $3 \%$ goat serum and then incubated with primary followed by secondary antibodies at optimised dilutions in phosphate-buffered isotonic saline plus 1\% BSA. Pre-immune sera, irrelevant isotype-matched monoclonal antibodies and secondary antibodies (used without primary antibodies) served as negative controls. The monoclonal antibody 18.6, which recognises an acrosome-associated antigen (Moore et al. 1987), was also used as a positive control and was a kind gift of H D M Moore, University of Sheffield. DNA was stained through the Vectashield mounting medium including either 4',6-diamidino-2-phenylindole (DAPI) or propidium iodide (Vector Laboratories, Peterborough, UK). Slides were examined using an epifluorescence microscope (Olympus, Prague, Czech Republic) and images were taken using a TCS SP2 RS high-speed confocal/two-photon system (Leica, Prague, Czech Republic) for live cell imaging and dynamics.

\section{Acknowledgements}

We are grateful to M Mizuno, C L Harris and B P Morgan (Cardiff, UK) for providing anti-CD46 antibodies. The Apodemus CD46 sequences are available at the GenBank database under accession numbers EF216471, EF216472 and EF216473. Financial support was from the Heggie Trust, GACR 206/04/ 0493 and MSMT VZ 0021620828. The authors declare that there is no conflict of interest that would prejudice the impartiality of this scientific work.

\section{References}

Anderson DJ, Michaelson JS \& Johnson PM 1989 Trophoblast/leukocytecommon antigen is expressed by human testicular germ cells and appears on the surface of acrosome-reacted sperm. Biology of Reproduction 41 285-293.

Anderson DJ, Abbott AF \& Jack RM 1993 The role of complement component $\mathrm{C} 3 \mathrm{~b}$ and its receptors in sperm-oocyte interaction. PNAS $\mathbf{9 0}$ 10051-10055.

Breed WG \& Taylor J 2000 Body mass, testes, and sperm size in murine rodents. Journal of Mammalogy $\mathbf{8 1} 758-768$.

Bryja J \& Stopka P 2005 Facultative promiscuity in a presumably monogamous mouse Apodemus microps. Acta Theriologica $\mathbf{5 0}$ 189-196.

Cattaneo R 2004 Four viruses, two bacteria, and one receptor: membrane cofactor protein (CD46) as pathogens' magnet. Journal of Virology $\mathbf{7 8}$ 4385-4388.

Cervoni F, Oglesby TJ, Adams EM, Milesifluet C, Nickells M, Fenichel P, Atkinson JP \& Hsi B-L 1992 Identification and characterization of membrane cofactor protein of human spermatozoa. Journal of Immunology 148 1431-1437.

D'Cruz OJ, Lambert H \& Haas GG 1997 Expression of CD15 (Lewisx) antigen on human sperm and its role in sperm-egg interaction. American Journal of Reproductive Immunology 37 172-183. 
Gomendio M, Martin-Coello J, Crespo C, Magana C \& Roldan ERS 2006 Sperm competition enhances functional capacity of mammalian spermatozoa. PNAS 103 15113-15117.

Hosokawa M, Nonaka M, Okada N, Nonaka M \& Okada H 1996 Molecular cloning of guinea pig membrane cofactor protein: preferential expression in testis. Journal of Immunology 157 4946-4952.

Huang TT, Fleming AD \& Yanagimachi R 1981 Only acrosome-reacted spermatozoa can bind to and penetrate zona pellucida: a study using the guinea pig. Journal of Experimental Zoology 217 287-290.

Immler S, Moore HD, Breed WG \& Birkhead TR 2007 By hook or by crook? Morphometry, competition and cooperation in rodent sperm PLOS ONE 2 e170.

Inoue N, Ikawa $M$, Nakanishi T, Matsumoto $M$, Nomura $M$, Seya $T$ \& Okabe M 2003 Disruption of mouse CD46 causes an accelerated spontaneous acrosome reaction in sperm. Molecular and Cellular Biology 23 2614-2622.

Källström H, Islam MS, Berggren PO \& Jonsson AB 1998 Cell signaling by the type IV pili of pathogenic Neisseria. Journal of Biological Chemistry 273 21777-21782.

Kemper C, Chan AC, Green JM, Brett KA, Murphy KM \& Atkinson JP 2003 Activation of human $\mathrm{CD}^{+}{ }^{+}$cells with CD3 and CD46 induces a T-regulatory cell phenotype. Nature 421 388-392.

Klemm M \& Engel W 1991 On the capacity of mouse spermatozoa for spontaneous acrosome reaction in the male and female genital tract. Andrologia 23 427-433.

Kurita-Taniguchi M, Hazeki K, Murabayashi N, Fukui A, Tsuji S, Matsumoto M, Toyoshima K \& Seya T 2002 Molecular assembly of CD46 with CD9, alpha3-beta1 integrin and protein tyrosine phosphatase SHP-1 in human macrophages through differentiation by GM-CSF. Molecular Immunology 38 689-700.

Levitan DR \& Ferrell DL 2006 Selection on gamete recognition proteins depends on sex, density and genotype frequency. Science 312 267-269.

Liszewski MK \& Atkinson JP 1992 Membrane cofactor protein. Current Topics in Microbiology and Immunology 178 45-60.

Liszewski MK, Kemper C, Price JD \& Atkinson JP 2005 Emerging roles and new functions of CD46. Springer Seminars in Immunopathology 27 345-358.

Lozahic S, Christiansen D, Manié S, Gerlier D, Billard M, Boucheix C \& Rubinstein E 2000 CD46 (membrane cofactor protein) associates with multiple $\beta 1$ integrins and tetraspans. European Journal of Immunology 30 900-907.

Marie JC, Astier AL, Rivailler P, Rabourdin-Combe C, Wild TF \& Horvat B 2002 Linking innate and acquired immunity: divergent role of CD46 cytoplasmic domains in T cell-induced inflammation. Nature Immunology 3 659-666.

Mead R, Hinchliffe SJ \& Morgan BP 1999 Molecular cloning, expression and characterization of the rat analogue of human membrane cofactor protein (MCP/CD46). Immunology 98 137-143.

Michaux JR, Chevret P, Filippucci MG \& Macholan M 2002 Phylogeny of the genus Apodemus with a special emphasis on the subgenus Sylvaemus using the nuclear IRBP gene and two mitochondrial markers: cytochrome $\mathrm{b}$ and $12 \mathrm{~S}$ rRNA. Molecular Phylogenetics and Evolution 23 123-136.

Miwa T, Nonaka M, Okada N, Wanaka S, Shiroishi T \& Okada H 1998 Molecular cloning of rat and mouse membrane cofactor protein (MCP, CD46): preferential expression in testis and close linkage between the mouse Mcp and $\mathrm{Cr} 2$ genes on distal chromosome 1. Immunogenetics $\mathbf{4 8}$ 363-371.

Mizuno M, Harris CL, Johnson PM \& Morgan BP 2004 Rat membrane cofactor protein (MCP; CD46) is expressed only in the acrosome of developing and mature spermatozoa and mediates binding to immobilized activated C3. Biology of Reproduction 71 1374-1383.

Mizuno M, Harris CL, Suzuki N, Matsuo S \& Morgan BP 2005 Expression of CD46 in developing rat spermatozoa: ultrastructural localization and utility as a marker of the various stages of the seminiferous tubuli. Biology of Reproduction 72 908-915.

Mizuno M, Harris CL \& Morgan BP 2007 Immunization with autologous CD46 in rats generates a strong autoantibody response that targets spermatozoa. Journal of Reproductive Immunology 73 135-147.

Moore HD, Smith CA, Hartman TD \& Bye AP 1987 Visualization and characterization of the acrosome reaction of human spermatozoa by immunolocalization with monoclonal antibody. Gamete Research 17 245-249.
Moore H, Dvorakova K, Jenkins N \& Breed W 2002 Exceptional sperm cooperation in the wood mouse. Nature 418 174-177.

Myles DG, Hyatt H \& Primakoff P 1987 Binding of both acrosome-intact and acrosome-reacted guinea pig sperm to the zona pellucida during in vitro fertilization. Developmental Biology $121559-567$.

Naito K, Toyoda Y \& Yanagimachi R 1992 Production of normal mice from oocytes fertilized and developed without zonae pellucidae. Human Reproduction 7 281-285.

Okabe M, Nagira M, Kawai Y, Matzno S, Mimura T \& Mayumi T 1990 A human sperm antigen possibly involved in binding and/or fusion with zona-free hamster eggs. Fertility and Sterility 54 1121-1126.

Pasten C, Morales P \& Kong M 2005 Role of the sperm proteasome during fertilization and gamete interaction in the mouse. Molecular Reproduction and Development 71 209-219.

Rezcallah MS, Hodges K, Gill DB, Atkinson JP, Wang B \& Cleary PP 2005 Engagement of CD46 and $\alpha 5 \beta 1$ integrin by group $A$ streptococci is required for efficient invasion of epithelial cells. Cellular Microbiology 7 645-653.

Riley RC, Kemper C, Leung M \& Atkinson JP 2002a Characterization of human membrane cofactor protein (MCP; CD46) on spermatozoa. Molecular Reproduction and Development 62 534-546.

Riley RC, Tannenbaum PL, Abbott DH \& Atkinson JP 2002b Inhibiting measles virus infection but promoting reproduction: an explanation for splicing and tissue-specific expression of CD46. Journal of Immunology 169 5405-5409.

Riley-Vargas RC, Lanzendorf S \& Atkinson JP 2005 Targeted and restricted complement activation on acrosome-reacted spermatozoa. Journal of Clinical Investigation 115 1241-1249.

Serizawa K, Suzuki H \& Tsuchiya K 2000 A phylogenetic view on species radiation in Apodemus inferred from variation of nuclear and mitochondrial genes. Biochemical Genetics 38 27-40.

Simmons LW \& Roberts B 2005 Bacterial immunity traded for sperm viability in male crickets. Science 3092031.

Stoecklin G, Mayo T \& Anderson P 2006 ARE-mRNA degradation requires the $5^{\prime}-3^{\prime}$ decay pathway. EMBO Reports 7 72-77.

Talbot P, Shur BD \& Myles DG 2003 Cell adhesion and fertilization: steps in oocyte transport, sperm-zona pellucida interaction, and sperm-egg fusion. Biology of Reproduction 68 1-9.

Taylor CT, Biljan MM, Kingsland CR \& Johnson PM 1994 Inhibition of human spermatozoon-oocyte interaction in vitro by monoclonal antibodies to CD46 (membrane cofactor protein). Human Reproduction 9 907-911.

Tsujimura A, Shida K, Kitamura M, Nomura M, Takeda J, Tanaka H, Matsumoto M, Matsumiya K, Okuyama A, Nishimune Y et al. 1998 Molecular cloning of a murine homologue of membrane cofactor protein (CD46): preferential expression in testicular germ cells. Biochemical Journal 330 163-168.

Wang G, Liszewski MK, Chan AC \& Atkinson JP 2000 Membrane cofactor protein (MCP; CD46): isoform-specific tyrosine phosphorylation. Journal of Immunology 164 1839-1846.

Wong TC, Yant S, Harder BJ, Korte-Sarfaty J \& Hirano A 1997 The cytoplasmic domains of complement regulatory protein CD46 interact with multiple kinases in macrophages. Journal of Leukocyte Biology 62 892-900.

Yamagata K, Nakanishi T, Ikawa M, Yamaguchi R, Moss SB \& Okabe M 2002 Sperm from the calmegin-deficient mouse have normal abilities for binding and fusion to the egg plasma membrane. Developmental Biology 250 348-357.

Zaffran Y, Destaing O, Roux A, Ory S, Nheu T, Jurdic P, RabourdinCombe C \& Astier AL 2001 CD46/CD3 costimulation induces morphological changes of human $\mathrm{T}$ cells and activation of Vav, Rac, and extracellular signal-regulated kinase mitogen-activated protein kinase. Journal of Immunology 167 6780-6785.

Received 3 August 2007

First decision 2 October 2007

Accepted 2 October 2007 